\title{
Effect of plant growth on some physical properties of potting culture media
}

\author{
A. Mohammadi-Ghehsareh ${ }^{1}$
}

Received: 8 November 2014/Accepted: 1 June 2015/Published online: 21 July 2015

(c) The Author(s) 2015. This article is published with open access at Springerlink.com

\begin{abstract}
Background Physical properties of substrates considered appropriate for plant growth at planting may change over time in containers as a result of several processes. Changes include air space reduction, shrinkage of the substrate, organic matter decomposition, and physical breakdown of particles. The objective of this research was to evaluate the physical properties of date palm waste as culture media and its effect on number and yield of tomato fruit.

Results The experiment was conducted as factorial in a completely randomized block design with 9 treatments and 3 replications. Treatments included three sizes $\left(S_{1}=<0.5\right.$, $S_{2}=0.5-1$, and $S_{3}=1-2 \mathrm{~cm}$ ) and three composting times ( $C_{1}=0, C_{2}=3$, and $C_{3}=6$ months) of date palm waste. Statistical analysis showed that the values of bulk density (BD) and water holding capacity (WHC) were significantly increased at the end of cultivation from culture media without plant in comparison to before and after planting $(p<0.05)$. Amounts of $F_{\mathrm{t}}$ (total porosity) in culture media without plant were significantly higher than those in culture media before planting and with plant $(p<0.05)$. Also during the experiment, an apparent shift in physical properties was recorded.

Conclusion The overall results of this research indicated that composting process changed the physical properties of the media before planting. Also during the experiment, an apparent shift in physical properties was recorded. The results of the study showed that composting processes
\end{abstract}

A. Mohammadi-Ghehsareh mghehsareh@yahoo.com

1 Department of Soil Science, Faculty of Agriculture, Islamic Azad University of Isfahan, P.O. Box 81595-158, Isfahan, Iran continued in culture media with and without plant, in the mean time, the composting processes were higher in culture media without plant.

Keywords Soilless culture $\cdot$ Culture media $\cdot$ Date palm waste $\cdot$ Physical properties

\section{Introduction}

Beginning in the early 1970s, the search for organic soilless substrates for container production has been an important horticultural research topic with the introduction of hardwood and softwood barks as the primary component in nursery container substrates (Aaron 1982; Hoitink and Poole 1979). Container substrates should maintain adequate air space (AS) and container capacity [CC; which is the equivalent to the water holding capacity (WHC) of a substrate] during crop production so that growing conditions remain favorable for plant growth. Physical properties of substrates considered appropriate for plant growth at planting may change over time in containers as a result of several processes (Allaire-Leung et al. 1999; Lemaire 1995). Changes include air space reduction as a result of settling and segregation of particles of variable sizes (Bilderback and Lorscheider 1995), shrinkage of the substrate (Bruckner 1997), organic matter decomposition, and physical breakdown of particles (Bollen and Glennie 1961; Nash and Laiche 1981). Current guidelines for nursery container substrates suggest that after irrigation and drainage, substrates should have 10-30 \% AS, 45-65\% CC, 25-35\% available water, 25-35\% unavailable water, 50-85\% total porosity (TP), and $0.19-0.70 \mathrm{~g} / \mathrm{cm}^{-3}$ bulk density (BD) (Yeager et al. 2007). The success of a horticultural substrate is mainly 
based on the behavior of the plants grown in them; highquality substrates with the proper physical and chemical properties can result in high yields and excellent plant quality (Verdonck and Gabriels 1992). The objective of this research was to evaluate the physical properties of date-palm waste as culture media and its effect on number and yield of tomato fruit.

\section{Materials and methods}

This research was performed in the greenhouse research site of Isfahan Azad University (Khorasgan). The experiment was conducted as factorial in a completely randomized block design with 9 treatments and 3 replications. Palm wastes were chopped into smaller sizes by combine, and chopped wastes are separated in three sizes $(<0.5$, $0.5-1$, and $1-2 \mathrm{~cm}$ ) by sieve. Then, they were kept in $1.5 \mathrm{~m}^{3}$ plastic bags for controlling the moisture and temperature. Some amounts of animal fertilizer $(10 \mathrm{~g} / \mathrm{kg})$ and $\mathrm{N}$ and $\mathrm{P}$ fertilizers $(4 \mathrm{~g} / \mathrm{kg}$ from urea and $4 \mathrm{~g} / \mathrm{kg}$ super phosphate fertilizers) were added to them as a fermentation starter, and these bags were placed in hot $\left(25-30{ }^{\circ} \mathrm{C}\right)$ condition. For respiration, some air holes were made on the bags and the moisture was adjusted to $65 \%$. Every week, these materials were mixed together and put into the bags again (during the 3 and 6 months). Then, these date palm wastes were used as culture media for tomato cultivation. Treatments included three composting times $(C)$ and three sizes $(S)$ as explained in Table 1.

Physical characteristics of the culture media including bulk density and article density (Baruah and Barthakur 1998; Daifullah et al. 2003), water holding capacity (WHC) (Verdonck and Gabriels 1992), and porosity (Baruah and Barthakur 1998) were measured before planting and after plant harvested from the culture media without and with plant. Seeds of tomato (Izmir cultivar) were planted in cocopeat. The $F_{\mathrm{t}}$ (total porosity) was measured using $F_{\mathrm{t}}=1-\left(\rho_{\mathrm{b}} / \rho_{\mathrm{s}}\right)\left(\rho_{\mathrm{b}}\right.$ and $\rho_{\mathrm{s}}$ are bulk

Table 1 Definition of experiment treatments

\begin{tabular}{ll}
\hline Treatments & Definition \\
\hline$C_{1} S_{1}$ & Size $0-0.5 \mathrm{~cm}+0$ month composing period \\
$C_{2} S_{1}$ & Size $0-0.5 \mathrm{~cm}+3$ months composing period \\
$C_{3} S_{1}$ & Size $0-0.5 \mathrm{~cm}+6$ months composing period \\
$C_{1} S_{2}$ & Size $0.5-1 \mathrm{~cm}+0$ month composing period \\
$C_{2} S_{2}$ & Size $0.5-1 \mathrm{~cm}+3$ months composing period \\
$C_{3} S_{2}$ & Size $0.5-1 \mathrm{~cm}+6$ months composing period \\
$C_{1} S_{3}$ & Size $1-2 \mathrm{~cm}+0$ month composing period \\
$C_{2} S_{3}$ & Size $1-2 \mathrm{~cm}+3$ months composing period \\
$C_{3} S_{3}$ & Size $1-2 \mathrm{~cm}+6$ months composing period \\
\hline
\end{tabular}

density and article density, respectively) (Baruah and Barthakur 1998). After transplanting growth, they were transferred to 10-1 pots filled with above treatments. Irrigation was done by hand and Papadopolus (1991) formula with fertigation method was used for nutrient solution. Average temperature of day and night were 30 and $18{ }^{\circ} \mathrm{C}$, respectively, in greenhouse. During plant growth, irrigation rate, temperature, humidity, and pest control for all treatments were similar. Leaching ( $20 \%$ ) of culture media was performed every 15 days. Plant height (from pot top to plant tip), root dry weight (plant root separated from culture media by washing with water and dried in oven), and stem diameter (from pot top) (by caliper) of tomato plants were measured. Experimental data normality was verified, and then data were submitted to analysis of variance, using SAS (1997) software package. Means were compared using Duncan multiple test $(p<0.05)$.

\section{Results and discussion}

Tables 2, 3, and 4 show some physical properties of culture media before planting, without and with plant, respectively. Maximum BD values in culture media before planting (Table 2) and without (Table 3) and with plant (Table 4) were related to culture media $C_{1} S_{1}(p<0.05)$. It was because of more entered dust in this size during the crashing and sieving. With increasing size fractions, bulk density decreased. It could be due to bigger pores and higher porosity in larger sizes. In each size, culture media with more composting time (6 months) had more bulk density than culture media with lower composting time (3 months). Carbon (C) compounds present in organic matters are used by microorganisms as an energy source. As $\mathrm{C}$ is lost from the compost pile, the compost becomes

Table 2 Physical properties of the culture media before planting (before experiment)

\begin{tabular}{llll}
\hline Treatment & $\mathrm{BD}\left(\mathrm{g} / \mathrm{cm}^{3}\right)$ & $F_{\mathrm{t}}(\%)$ & WHC $(\%)$ \\
\hline$C_{1} S_{1}$ & $0.25^{\mathrm{a}}$ & $83^{\mathrm{e}}$ & $89.65^{\mathrm{c}}$ \\
$C_{2} S_{1}$ & $0.18^{\mathrm{c}}$ & $88^{\mathrm{c}}$ & $94.26^{\mathrm{a}}$ \\
$C_{3} S_{1}$ & $0.19^{\mathrm{b}}$ & $87^{\mathrm{d}}$ & $92.62^{\mathrm{b}}$ \\
$C_{1} S_{2}$ & $0.17^{\mathrm{d}}$ & $89^{\mathrm{b}}$ & $57.5^{\mathrm{g}}$ \\
$C_{2} S_{2}$ & $0.18^{\mathrm{c}}$ & $88^{\mathrm{c}}$ & $74.57^{\mathrm{d}}$ \\
$C_{3} S_{2}$ & $0.19^{\mathrm{b}}$ & $87^{\mathrm{d}}$ & $58.91^{\mathrm{f}}$ \\
$C_{1} S_{3}$ & $0.15^{\mathrm{f}}$ & $90^{\mathrm{a}}$ & $37.75^{\mathrm{i}}$ \\
$C_{2} S_{3}$ & $0.16^{\mathrm{e}}$ & $89^{\mathrm{b}}$ & $53.48^{\mathrm{h}}$ \\
$C_{3} S_{3}$ & $0.17^{\mathrm{d}}$ & $88^{\mathrm{c}}$ & $59.31^{\mathrm{e}}$ \\
\hline
\end{tabular}

Means followed by the same letter are not significantly different according to Duncan's multiple range test, $p<0.05$

$B D$ bulk density, $F_{t}$ total porosity, $W H C$ water holding capacity 
Table 3 Physical properties of the culture media without plant (after experiment)

\begin{tabular}{llll}
\hline Treatment & BD $\left(\mathrm{g} / \mathrm{cm}^{3}\right)$ & $F_{\mathrm{t}}(\%)$ & WHC $(\%)$ \\
\hline$C_{1} S_{1}$ & $0.27^{\mathrm{a}}$ & $81^{\mathrm{d}}$ & $93.05^{\mathrm{c}}$ \\
$C_{2} S_{1}$ & $0.19^{\mathrm{f}}$ & $86^{\mathrm{a}}$ & $94.03^{\mathrm{a}}$ \\
$C_{3} S_{1}$ & $0.20^{\mathrm{e}}$ & $86^{\mathrm{a}}$ & $94.26^{\mathrm{a}}$ \\
$C_{1} S_{2}$ & $0.20^{\mathrm{e}}$ & $86^{\mathrm{a}}$ & $62.13^{\mathrm{f}}$ \\
$C_{2} S_{2}$ & $0.19^{\mathrm{f}}$ & $86^{\mathrm{a}}$ & $78.11^{\mathrm{d}}$ \\
$C_{3} S_{2}$ & $0.19^{\mathrm{f}}$ & $86^{\mathrm{a}}$ & $63.03^{\mathrm{e}}$ \\
$C_{1} S_{3}$ & $0.25^{\mathrm{b}}$ & $82^{\mathrm{c}}$ & $40.09^{\mathrm{i}}$ \\
$C_{2} S_{3}$ & $0.24^{\mathrm{c}}$ & $82^{\mathrm{c}}$ & $56.11^{\mathrm{h}}$ \\
$C_{3} S_{3}$ & $0.22^{\mathrm{d}}$ & $84^{\mathrm{b}}$ & $61.13^{\mathrm{g}}$ \\
\hline
\end{tabular}

Means followed by the same letter are not significantly different according to Duncan's multiple range test, $p<0.05$

$B D$ bulk density, $F_{t}$ total porosity, $W H C$ water holding capacity

Table 4 Physical properties of the culture media with plant (after plant harvested)

\begin{tabular}{llll}
\hline Treatment & BD $\left(\mathrm{g} / \mathrm{cm}^{3}\right)$ & $F_{\mathrm{t}}(\%)$ & WHC $(\%)$ \\
\hline$C_{1} S_{1}$ & $0.20^{\mathrm{a}}$ & $86^{\mathrm{e}}$ & $91.00^{\mathrm{c}}$ \\
$C_{2} S_{1}$ & $0.17^{\mathrm{c}}$ & $89^{\mathrm{c}}$ & $95.07^{\mathrm{a}}$ \\
$C_{3} S_{1}$ & $0.18^{\mathrm{b}}$ & $88^{\mathrm{d}}$ & $95.16^{\mathrm{a}}$ \\
$C_{1} S_{2}$ & $0.16^{\mathrm{d}}$ & $90^{\mathrm{b}}$ & $58.10^{\mathrm{g}}$ \\
$C_{2} S_{2}$ & $0.17^{\mathrm{c}}$ & $89^{\mathrm{c}}$ & $75.06^{\mathrm{d}}$ \\
$C_{3} S_{2}$ & $0.18^{\mathrm{b}}$ & $88^{\mathrm{d}}$ & $59.6^{\mathrm{f}}$ \\
$C_{1} S_{3}$ & $0.14^{\mathrm{f}}$ & $91^{\mathrm{a}}$ & $38.77^{\mathrm{h}}$ \\
$C_{2} S_{3}$ & $0.15^{\mathrm{e}}$ & $90^{\mathrm{b}}$ & $54.30^{\mathrm{h}}$ \\
$C_{3} S_{3}$ & $0.16^{\mathrm{d}}$ & $89^{\mathrm{c}}$ & $60.10^{\mathrm{e}}$ \\
\hline
\end{tabular}

Means followed by the same letter are not significantly different according to Duncan's multiple range test, $p<0.05$

$B D$ bulk density, $F_{t}$ total porosity, $W H C$ water holding capacity

more condensed and air spaces within the pile become smaller (Smith Hirrel and Riley 2012). Kaila (1956) reported that bulk density could be used as a basis for estimating the degree of decomposition of peats. Before and after planting, the highest amounts of porosity were observed in culture media $C_{1} S_{3}$ because of lower bulk density and bigger pores between them. The porosity percentage is an index for root aeration in culture media. When root media aeration is sufficient, supply of water and nutrient elements for plant is easier. In culture media before planting, the maximum amount of WHC was related to culture media $C_{2} S_{1}$. WHC in culture media is related to particle size and pore size. Smaller particles have a larger surface area than those with larger particles; a large surface area allows a medium to hold more moisture and to increase WHC which causes poor air-water relationship, leading to low aeration within the medium and effect on oxygen diffusion to the roots. The highest amounts of WHC in culture media without and with plant were significantly recorded in culture media $C_{2} S_{1}$ and $C_{3} S_{1}$ $(p<0.05)$. Organic matter degradation caused particles to be more chopped in compost pile and so surface area and WHC were increased.

Comparison means of physical properties of culture media before planting, at the end of cultivation from culture media without and with plant in each treatment are shown in Table 5. Values of BD were significantly increased at the end of cultivation from culture media without plant in comparison to culture media before planting and after planting $(p<0.05)$. The lowest BD was significantly observed in culture media with plant $(p<0.05)$. Plants can affect substrate structure by creating pores in substrates and decrease the bulk density of substrates through root channeling. Maximum $F_{\mathrm{t}}$ (total porosity) was significantly related to culture media with plant $(p<0.05)$ because of lower bulk density in culture media with plant. Amounts of WHC in culture media without plant were significantly higher than those in culture media with plant and before planting $(p<0.05)$. It could be due to increasing composting process in culture media without plant in comparison to culture media with plant that is related to microorganism population and activity, because in culture media without plant main section of nutritional elements were consumed by microorganisms and led to more activity in composting process in comparison to culture media with plant that is consumed by plant. Organic matter degradation caused particles to be more chopped in compost pile and so surface area and WHC were increased.

Table 6 illustrates the effect of treatments on some growing indexes of tomato plants. Culture media had a significant effect on root dry weight of tomato plants $(p<0.05)$. Highest root dry weight was related to culture media $C_{1} S_{3}$ because of highest porosity in this media as compared with other treatments $(p<0.05)$. Highest amount of plant height was significantly observed in treatment $C_{1} S_{3}(p<0.05)$. Bulk density and porosity in this media had proper conditions and caused better suport of water and nutrient elements for plant leading to good growth (Olympious 1992; Kumar and Goh 1999). Culture media had no significant effect on stem diameter of tomato plants. Borji et al. (2010) showed that different substrates including date-palm peat 1 (without composting period), date-palm peat 2 (with 3 months composting period), perlite, cocopeat + date-palm peat $2(\mathrm{v} / \mathrm{v}=50 \%)$, cocopeat + date-palm peat $1(\mathrm{v} / \mathrm{v} /=50 \%)$, perlite + date-palm peat $2(\mathrm{v} / \mathrm{v}=50 \%)$, perlite + date-palm peat $1(\mathrm{v} /$ $\mathrm{v}=50 \%$ ), and cocopeat + perlite had no significant difference in stem diameter of tomato plant. 
Table 5 Comparison means of physical properties of the culture media before planting (b) and at the end of cultivation from culture media without (c) and with plant (p) in each treatment

\begin{tabular}{llllllllll}
\hline Physical properties & \multicolumn{7}{l}{ Treatments } \\
\cline { 2 - 9 } & $C_{1} S_{1}$ & $C_{2} S_{1}$ & $C_{3} S_{1}$ & $C_{1} S_{2}$ & $C_{2} S_{2}$ & $C_{3} S_{2}$ & $C_{1} S_{3}$ & $C_{2} S_{3}$ & $C_{3} S_{3}$ \\
\hline$(\mathrm{BD})_{\mathrm{b}}$ & $0.25^{\mathrm{b}}$ & $0.18^{\mathrm{b}}$ & $0.19^{\mathrm{b}}$ & $0.17^{\mathrm{b}}$ & $0.18^{\mathrm{b}}$ & $0.19^{\mathrm{a}}$ & $0.15^{\mathrm{b}}$ & $0.16^{\mathrm{b}}$ & $0.17^{\mathrm{b}}$ \\
$(\mathrm{BD})_{\mathrm{p}}$ & $0.2^{\mathrm{c}}$ & $0.17^{\mathrm{c}}$ & $0.18^{\mathrm{c}}$ & $0.16^{\mathrm{c}}$ & $0.17^{\mathrm{c}}$ & $0.18^{\mathrm{b}}$ & $0.14^{\mathrm{c}}$ & $0.15^{\mathrm{c}}$ & $0.16^{\mathrm{c}}$ \\
$(\mathrm{BD})_{\mathrm{c}}$ & $0.27^{\mathrm{a}}$ & $0.19^{\mathrm{a}}$ & $0.20^{\mathrm{a}}$ & $0.20^{\mathrm{a}}$ & $0.19^{\mathrm{a}}$ & $0.19^{\mathrm{a}}$ & $0.25^{\mathrm{a}}$ & $0.24^{\mathrm{a}}$ & $0.22^{\mathrm{a}}$ \\
$\left(F_{\mathrm{t}}\right)_{\mathrm{b}}$ & $83^{\mathrm{b}}$ & $88^{\mathrm{b}}$ & $87^{\mathrm{b}}$ & $89^{\mathrm{b}}$ & $88^{\mathrm{b}}$ & $87^{\mathrm{b}}$ & $90^{\mathrm{b}}$ & $89^{\mathrm{b}}$ & $88^{\mathrm{b}}$ \\
$\left(F_{\mathrm{t}}\right)_{\mathrm{p}}$ & $86^{\mathrm{a}}$ & $89^{\mathrm{a}}$ & $88^{\mathrm{a}}$ & $90^{\mathrm{a}}$ & $89^{\mathrm{a}}$ & $88^{\mathrm{a}}$ & $91^{\mathrm{a}}$ & $90^{\mathrm{a}}$ & $89^{\mathrm{a}}$ \\
$\left(F_{\mathrm{t}}\right)_{\mathrm{c}}$ & $81^{\mathrm{c}}$ & $86^{\mathrm{c}}$ & $86^{\mathrm{c}}$ & $86^{\mathrm{c}}$ & $86^{\mathrm{c}}$ & $86^{\mathrm{c}}$ & $82^{\mathrm{c}}$ & $82^{\mathrm{c}}$ & $84^{\mathrm{c}}$ \\
$(\mathrm{WHC})_{\mathrm{b}}$ & $89.65^{\mathrm{c}}$ & $94.26^{\mathrm{c}}$ & $92.62^{\mathrm{b}}$ & $57.5^{\mathrm{c}}$ & $74.57^{\mathrm{c}}$ & $58.91^{\mathrm{c}}$ & $37.75^{\mathrm{b}}$ & $53.48^{\mathrm{c}}$ & $59.31^{\mathrm{c}}$ \\
$(\mathrm{WHC})_{\mathrm{p}}$ & $91^{\mathrm{b}}$ & $95.16^{\mathrm{b}}$ & $95.07^{\mathrm{b}}$ & $58.1^{\mathrm{b}}$ & $75.06^{\mathrm{b}}$ & $59.6^{\mathrm{b}}$ & $38.77^{\mathrm{b}}$ & $59.3^{\mathrm{b}}$ & $60.1^{\mathrm{b}}$ \\
$(\mathrm{WHC})_{\mathrm{c}}$ & $93^{\mathrm{a}}$ & $94.26^{\mathrm{a}}$ & $94.03^{\mathrm{a}}$ & $62.13^{\mathrm{a}}$ & $78.11^{\mathrm{a}}$ & $58.91^{\mathrm{c}}$ & $40.09^{\mathrm{a}}$ & $56.11^{\mathrm{a}}$ & $61.13^{\mathrm{a}}$ \\
\hline
\end{tabular}

Means followed by the same letter are not significantly different according to Duncan's multiple range test, $p<0.05$

$B D$ bulk density, $F_{t}$ total porosity, $W H C$ water holding capacity

\begin{tabular}{llll}
\hline Treatment & Plant height $(\mathrm{cm})$ & Stem diameter $(\mathrm{cm})$ & Root dry weight $(\mathrm{g})$ \\
\hline$C_{1} S_{1}$ & $105.19^{\mathrm{e}}$ & $2.19^{\mathrm{c}}$ & $3^{\mathrm{e}}$ \\
$C_{2} S_{1}$ & $105.09^{\mathrm{e}}$ & $2.11^{\mathrm{c}}$ & $3.3^{\mathrm{c}}$ \\
$C_{3} S_{1}$ & $105.12^{\mathrm{e}}$ & $2.41^{\mathrm{a}}$ & $3.08^{\mathrm{de}}$ \\
$C_{1} S_{2}$ & $118.72^{\mathrm{c}}$ & $2.27^{\mathrm{b}}$ & $3.7^{\mathrm{b}}$ \\
$C_{2} S_{2}$ & $118.1^{\mathrm{d}}$ & $2.34^{\mathrm{b}}$ & $3.29^{\mathrm{c}}$ \\
$C_{3} S_{2}$ & $120.08^{\mathrm{b}}$ & $2.59^{\mathrm{a}}$ & $3.11^{\mathrm{d}}$ \\
$C_{1} S_{3}$ & $121.16^{\mathrm{a}}$ & $2.13^{\mathrm{c}}$ & $4^{\mathrm{a}}$ \\
$C_{2} S_{3}$ & $118.13^{\mathrm{d}}$ & $2.44^{\mathrm{a}}$ & $3.7^{\mathrm{b}}$ \\
$C_{3} S_{3}$ & $118.08^{\mathrm{d}}$ & $2.26^{\mathrm{b}}$ & $3.22^{\mathrm{c}}$ \\
\hline
\end{tabular}

Means followed by the same letter are not significantly different according to Duncan's multiple range test, $p<0.05$
Table 6 Effect of treatments on some growing indexes of tomato plants

\section{Conclusion}

The overall results of this research indicated that composting process changed the physical properties of the media before planting. Also during the experiment, an apparent shift in physical properties was recorded. Physical properties generally refer to culture media ability to buffer the water held against changes in either $\mathrm{pH}$ or nutrition. The results showed that composting processes were continued in culture media without and with plant. It seems that the speed of composting process in culture media without plant was higher than that in culture media with plant because in culture media with plant, when media was fertigated with nutrient solution, some of the nutrient elements were used by plant and microorganisms, but in the culture media without plant these nutrient elements were used only by microorganisms and led to more activity. Mature compost increased the number and yield of tomato fruits.
Open Access This article is distributed under the terms of the Creative Commons Attribution 4.0 International License (http://creativecommons.org/licenses/by/4.0/), which permits unrestricted use, distribution, and reproduction in any medium, provided you give appropriate credit to the original author(s) and the source, provide a link to the Creative Commons license, and indicate if changes were made.

\section{References}

Aaron JR (1982) Conifer bark: its properties and uses. Forest Commun. Forest Rec, p 110

Allaire-Leung SE, Caron J, Parent LE (1999) Changes in physical properties of peat substrates during plant growth. Can J Soil Sci 79:137-139

Baruah TC, Barthakur HB (1998) A textbook of soil analysis. PMT Ltd, (Vikas Publishing House), New Delhi, p 282

Bilderback TE, Lorscheider MR (1995) Physical properties of doubleprocessed pine bark: effects on rooting. Acta Hort 401:77-83

Bollen WB, Glennie DW (1961) Sawdust, bark, and other wood wastes for soil conditioning and mulching. Forest Prod J $11: 38-46$ 
Borji H, Mohammadi-Ghehsareh A, Jafarpour M (2010) Effects of the substrate on tomato in soilless culture. Res J Agri Biol Sci 6(6):923-927

Bruckner U (1997) Physical properties of different potting media and substrate mixtures - especially air-and water capacity. Acta Hort 450:263-270

Daifullah AAM, Girgis BS, Gad HMH (2003) Utilization of agroresidues (rice husk) in small waste water treatment plans. Mater Lett 57:1723-1731

Hoitink HA, Poole HA (1979) Mass production of composted tree barks for container media. Ohio Flor Assn Bull 599:3-4

Kaila A (1956) Determination of the degree of humification of peat samples. J Sci Agri Soci Finland 28:18-35

Kumar K, Goh KM (1999) Crop residues and management practices: effects on soil quality, soil nitrogen dynamics, crop yield, and nitrogen recovery. J Adv Agron 68:197-319

Lemaire F (1995) Physical, chemical, and biological properties of growing medium. Acta Hort 396:273-284

Nash VE, Laiche AJ (1981) Changes in the characteristics of potting media with time. Commun Soil Sci Plant Anal 12:1011-1020
Olympious CM (1992) Soilless media under protected cultivation rockwool, peat, perlite and other substrates. Acta Hortic 401:443-451

Papadopolus AD (1991) Growing greenhouse tomatoes in soil and soilless. Communication Branch, Agric. Canada. Ottawa, pp 79

SAS Institute (1997) SAS user's guide statistics. SAS Institute Inc., Cary

Smith Hirrel S, Riley T (2012) Understanding the composting process. University of Arkansas, United States Department of Agriculture, and County Governments Cooperating

Verdonck O, Gabriels R (1992) Reference method for the determination of physical properties of plant substrates. II. Reference method for the determination of chemical properties of plant substrates. Acta Horticulturae 302:169-179

Yeager TH, Fare DC, Lea-Cox J, Ruter J, Bilderback TE, Gilliam CH, Niemiera AX, Warren SL, Whitwell TE, Wright RD, Tilt KM (2007) Best management practices: guide for producing container-grown plants, 2nd edn. Southern Nurserymen's Assoc, Marietta 